STUDIA PRAWNO-EKONOMICZNE, T. CVII, 2018

PL ISSN 0081-6841; e-ISSN 2450-8179 s. 83-92

https://doi.org/10.26485/SPE/2018/107/5

Paweł KSIĘŻAK*

\title{
GLOSA DO POSTANOWIENIA SĄDU NAJWYŻSZEGO Z DNIA 27 WRZEŚNIA 2017 R., V CSK 50/17
}

W komentowanym orzeczeniu Sąd Najwyższy rozstrzygnął problem, który ma istotne znaczenie praktyczne, a przy tym stanowi jedynie przypadek szczególny szerszego zagadnienia. Zajęte stanowisko odnośnie do zaliczania na schedę spadkową kwot wypłaconych przez bank na skutek realizacji dyspozycji wkładem bankowym na wypadek śmierci - jak się wydaje - można zuniwersalizować na inne wypadki bezpłatnych przysporzeń wynikających z pozatestamentowych dyspozycji mortis causa; nie ma też chyba przeszkód, by takie samo rozumowanie przeprowadzić w wypadku zachowku. W konsekwencji postanowienie będzie przydatne w szerokiej gamie spraw spadkowych. Może zaskakiwać, że dopiero teraz Sąd Najwyższy miał okazję wypowiedzieć się na ten temat. Z góry zaznaczam, że stanowisko Sądu Najwyższego zasługuje na aprobatę. Uwagi poniższe służyć mają uzupełnieniu i doprecyzowaniu argumentacji i wskazaniu innych przypadków, w których należy rozstrzygać tak samo.

Sprawa, w której wypowiadał się Sąd Najwyższy, dotyczyła działu spadku, podziału majątku wspólnego małżonków i zniesienia współwłasności. Zagadnieniem spornym był obowiązek zaliczenia na schedę spadkową współspadkobiercy kwoty wypłaconej tytułem dyspozycji wkładem bankowym na wypadek śmierci. Zgodnie $\mathrm{z}$ art. 56 ust. 1 prawa bankowego ${ }^{1}$ posiadacz rachunku oszczędnościowego, rachunku oszczędnościowo-rozliczeniowego lub rachunku terminowej lokaty oszczędnościowej może polecić pisemnie bankowi dokonanie - po swojej śmierci - wypłaty z rachunku wskazanym przez siebie osobom:

* Dr hab. prof. nadzw. Uniwersytet Łódzki, Wydział Prawa i Administracji, Katedra Prawa Cywilnego; e-mail: pksiezak@wpia.uni.lodz.pl

1 Ustawa z dnia 29 sierpnia 1997 r. - Prawo bankowe (tekst jedn. Dz.U. z 2017 r., poz. 1876). 
małżonkowi, wstępnym, zstępnym lub rodzeństwu określonej kwoty pieniężnej (dyspozycja wkładem na wypadek śmierci). Kwota wypłaty, o której mowa w ust. 1, bez względu na liczbę wydanych dyspozycji nie może być wyższa niż dwudziestokrotne przeciętne miesięczne wynagrodzenie w sektorze przedsiębiorstw bez wypłat nagród z zysku, ogłaszane przez Prezesa Głównego Urzędu Statystycznego za ostatni miesiąc przed śmiercią posiadacza rachunku (ust. 2). $Z$ kolei stosownie do art. 56 ust. 5 kwota wypłacona zgodnie z ust. 1 nie wchodzi do spadku po posiadaczu rachunku². Na marginesie odnotujmy, że analogiczne rozwiązanie zawiera art. 14 ust. 1 pkt 2 ustawy z dnia 5 listopada 2009 r. o spółdzielczych kasach oszczędnościowo-kredytowych ${ }^{3}$. Sąd Najwyższy przychylił się do stanowiska, że przez dyspozycję wkładem bankowym na wypadek śmierci spadkodawca dokonuje nieodpłatnego rozrządzenia swoim majątkiem na wypadek śmierci. Przypomniał również, że w uzasadnieniu uchwały z dnia 13 grudnia 2013 r. ${ }^{4}$ Sąd Najwyższy zakwalifikował tę dyspozycję jako rodzaj darowizny na wypadek śmierci.

Art. 1039 k.c. przewiduje, że jeżeli w razie dziedziczenia ustawowego dział spadku następuje między zstępnymi albo między zstępnymi i małżonkiem, spadkobiercy ci są wzajemnie zobowiązani do zaliczenia na schedę spadkową otrzymanych od spadkodawcy darowizn oraz zapisów windykacyjnych, chyba że z oświadczenia spadkodawcy lub z okoliczności wynika, że darowizna lub zapis windykacyjny zostały dokonane ze zwolnieniem od obowiązku zaliczenia. Zdaniem Sądu Najwyższego „,przez użyte w art. 1039 k.c. określenie «darowizna» należy rozumieć wszelkie przysporzenia dokonane przez spadkodawcę pod tytułem darmym. Ma ono zatem szersze znaczenie niż określenie

2 Podobne rozporządzenie - wkładem oszczędnościowym na wypadek śmierci wkładcy - ustawodawca przewidział w art. 39 ust. 1 pkt 2 ustawy z dnia 13 kwietnia 1960 r. o prawie bankowym (Dz.U., nr 20, poz. 121) od wejścia w życie, z dniem 3 marca 1964 r., ustawy z dnia 25 lutego 1964 r. o zmianie ustawy o prawie bankowym (Dz.U., nr 8, poz. 50). Następne, kolejno obowiązujące, ustawy zawierały również regulacje przewidujące rozporządzenie przez posiadacza rachunku bankowego na wypadek śmierci na rzecz wskazanych osób bliskich. W ustawie z dnia 12 czerwca 1975 r. - Prawo bankowe (Dz.U., nr 20, poz. 108) takiego rozporządzenia dotyczył art. 40 ust. 1 pkt 2; w ustawie z dnia 26 lutego 1982 r. - Prawo bankowe (Dz.U., nr 7, poz. 56 - art. 37 ust. 1 pkt 2; w ustawie z dnia 31 stycznia 1989 r. - Prawo bankowe (Dz.U., nr 4, poz. 21) - art. 22 ust. 1 pkt 2; w ustawie z dnia 29 sierpnia 1997 r. - Prawo bankowe (Dz.U., nr 140, poz. 939) art. 75 ust. 1 pkt 2 do dnia 1 maja 2004 r.

Tekst jedn.: Dz.U. z 2017 r., poz. 2065.

$4 \quad$ III CZP 79/13, OSNC 2014, nr 10, poz. 98 z glosami P. Księżaka, PiP 2015/10, s. 123-128;

I. Mazurkiewicz, Palestra 2015/11-12, s. 146-152; G. Wolaka, Rejent 2014/7, s. 117-136;

T. Justyńskiego, OSP 2014/10, poz. 91; J. Masiubańskiego, Rejent 2014/12, s. 115-130. 
«darowizna» z art. 888 k.c. Takie rozumienie czynności darmych ma realizować dorozumianą wolę spadkodawcy oraz doprowadzić do zrównania pozycji prawnej spadkobierców zstępnych i małżonka, którzy powinni być traktowani jednakowo". Do takich czynności należy także dyspozycja wkładem na wypadek śmierci. Zdaniem Sądu Najwyższego wyjątek od ogólnej reguły powinien być wyraźnie ustawowo uregulowany. Przepis art. 1039 § 1 k.c. ma jednak charakter dyspozytywny, tzn. umożliwia niezaliczenie na schedę spadkową otrzymanych przez spadkobiercę korzyści, jeżeli spadkodawca jednoznacznie wyraził taką wolę albo z okoliczności wynika, że przekazanie miało miejsce ze zwolnieniem od obowiązku zaliczenia.

Charakter prawny dyspozycji wkładem bankowym na wypadek śmierci jest sporny ${ }^{5}$. Nie ulega jednak wątpliwości, że w wyniku realizacji tej dyspozycji beneficjent otrzymuje korzyść bezpłatnie. To proste spostrzeżenie powinno być punktem wyjścia dla oceny tej dyspozycji na płaszczyźnie prawnospadkowej. Doliczanie darowizn to instytucja pojawiająca się zarówno przy dziale spadku, jak i przy zachowku. W obu wypadkach uzasadnienie dla tego mechanizmu jest inne: przy dziale spadku chodzi o uzupełnienie reguł dziedziczenia ustawowego $\mathrm{w}$ takim kierunku, by osiągnięty rezultat był sprawiedliwy, a zarazem zgodny z pewnym ogólnym wyobrażeniem o woli spadkodawcy. Spójrzmy na to przez pryzmat najprostszego przykładu. Jeżeli spadkodawca ma dzieci i nie sporządził testamentu, to ustawa za słuszne uważa przyjęcie, że każde z dzieci powinno dziedziczyć spadek w tej samej części. Niejednokrotnie zdarza się jednak, że spadkodawca już wcześniej jednemu z dzieci przekazał część swego majątku. Oczywiście do pomyślenia jest rozwiązanie, w którym takie przysporzenie pozostaje zupełnie obojętne dla kwestii dziedziczenia; polski ustawodawca widzi jednak potrzebę uwzględnienia tego przysporzenia w taki sposób, by ten, kto już otrzymał coś wcześniej, dostał ze spadku (czyli pozostałej części majątku) mniej. Ze względów techniczno-prawnych nie można tego oczywiście uwzględnić przy ustalaniu ułamka, w którym spadkobiercy dziedziczą (byłoby to bardzo skomplikowane), dlatego ewentualna korekta dokonuje się na etapie działu spadku. Jasne jest przy tym, że spadkodawca może wyrazić w tym zakresie inną wolę - doliczanie darowizn przy dziale spadku jest instytucją związaną przede wszystkim z dziedziczeniem ustawowym, zatem tak jak

\footnotetext{
Por. m.in. A. Szpunar, Wypłaty z rachunku oszczędnościowego po śmierci posiadacza, KPP 1998/3, s. 409 i n.; W. Pyziol, Pozatestamentowe formy dysponowania wktadem oszczędnościowym na wypadek śmierci, GSP 1999/2, s. 357 i n.; F. Rakiewicz, Charakter prawny dyspozycji wkładem na wypadek śmierci (art. 56 ustawy Prawo bankowe), cz. I, MoP 2005/19 i cz. II, MoP 2005/20.
} 
możliwe jest w testamencie ustalanie innych udziałów w spadku niż wskazuje ustawa (a nawet powołanie innych osób), tak samo możliwe jest decydowanie o tym, czy na ustawowo określony udział w spadku będą miały wpływ wcześniejsze przysporzenia. Inne uzasadnienie kryje się natomiast za doliczaniem darowizn przy zachowku: w tym wypadku ustawodawca uznaje za właściwe, by uprawnione osoby najbliższe spadkodawcy otrzymały określoną część majątku spadkodawcy (a ściślej - wartości tego majątku). Ochrona tych osób najbliższych wyprzedza przy tym wolę spadkodawcy, którego dyspozycje testamentowe nie wpływają na zakres tych uprawnien. Aby ochronę tę uczynić bardziej efektywną, podstawę obliczania zachowku stanowi nie tylko sam spadek, ale też wartość darowizn, których dokonał wcześniej spadkodawca. Dzięki temu uprawnieni chronieni są nie tylko przed niekorzystnymi dla nich rozrządzeniami testamentowymi, ale również wcześniejszymi czynnościami, które podobnie jak dziedziczenie prowadzą do bezpłatnego przysporzenia z majątku spadkodawcy. Oczywiście w tym wypadku doliczenie następuje niezależnie od woli spadkodawcy - chodzi bowiem tu o ochronę właśnie przed skutkami swobody testowania i dysponowania swoim majątkiem.

Po wprowadzeniu do naszego porządku prawnego zapisu windykacyjnego $^{6}$ zmianie uległy przepisy dotyczące działu spadku i zachowku w taki sposób, że doliczeniu podlegają obecnie nie tylko darowizny, ale również zapisy windykacyjne. Wynika to z faktu, że przedmiot zapisu windykacyjnego przechodzi na zapisobiercę $\mathrm{w}$ drodze sukcesji singularnej i nie wchodzi w skład spadku, jednakże sama odmienność technicznego sposobu sukcesji nie stanowi wystarczającego powodu, by pogorszyć sytuację spadkobierców ustawowych i osób uprawnionych do zachowku. To spostrzeżenie wydaje się w pełni aktualne również w odniesieniu do innych rodzajów sukcesji singularnej. Dyspozycja wkładem bankowym na wypadek śmierci analizowana w przywołanym kontekście działu spadku i zachowku jawi się jako instytucja prowadząca do tożsamych funkcjonalnie skutków co zapis windykacyjny. Należy zauważyć, że dyspozycja ta należy do jednego z instrumentów umożliwiających rozrządzenie majątkiem na wypadek śmierci. Testament jest najważniejszym, ale nie jedynym nośnikiem woli spadkodawcy co do losów jego majątku po jego śmierci. Chodzi zarówno o czynności jednostronne, jak i umowy (a ściślej - klauzule umowne), m.in. analizowaną tu dyspozycję. Szeroki katalog pozatestamentowych rozrządzeń na wypadek śmierci wynika przede wszystkim z przepisów

Ustawa z dnia 18 marca 2011 r. o zmianie ustawy - Kodeks cywilny oraz niektórych innych ustaw (Dz.U. z 2011 r., nr 85, poz. 458), która weszła w życie 23 października 2011 r. 
pozakodeksowych, które dotycząc określonych stosunków prawnych, przewidują również rozwiązania szczegółowe na wypadek śmierci strony tych stosunków. Są to przypadki, gdy dochodzi do pozaspadkowej sukcesji singularnej, przy czym spadkodawca ma możliwość wskazania beneficjenta przysporzenia. Będą to zatem przepisy, które w zakresie wskazania następców prawnych mają charakter dyspozytywny?

Obok wskazanych wcześniej przepisów prawa bankowego i ustawy o spółdzielczych kasach oszczędnościowo-kredytowych można wymienić jeszcze inne przykłady przepisów opartych na tej samej konstrukcji: art. 82 ustawy z dnia 28 sierpnia 1997 r. o organizacji i funkcjonowaniu funduszy emerytalnych ${ }^{8}$, który przewiduje możliwość wskazania osób, którym zostaną wypłacone niewykorzystane środki; art. 48 ustawy z dnia 20 kwietnia 2004 r. o pracowniczych programach emerytalnych ${ }^{9}$, który przewiduje możliwość wskazania na wypadek śmierci osoby uprawnionej do odbioru środków zgromadzonych na rachunku; art. 11 ustawy z dnia 20 kwietnia 2004 r. o indywidualnych kontach emerytalnych oraz indywidualnych kontach zabezpieczenia emerytalnego ${ }^{10}$, przewidujący możliwość wskazania osoby, której zostaną wypłacone zgromadzone środki w przypadku śmierci oszczędzającego; art. $16 \S 3$ ustawy z dnia 16 września 1982 r. - Prawo spółdzielcze ${ }^{11}$, który przewiduje możliwość wskazania osoby, której spółdzielnia wypłaci udziały po śmierci członka spółdzielni; art. 10d ust. 3 ustawy z dnia 7 grudnia 2000 r. o funkcjonowaniu banków spółdzielczych, ich zrzeszaniu się i bankach zrzeszających ${ }^{12}$, który przewiduje możliwość wskazania osoby, której po śmierci członka bank spółdzielczy jest obowiązany wypłacić udziały oraz inne należności związane z udziałami ${ }^{13}$.

7 Nie należą natomiast do tego zbioru te przepisy, które przewidują sukcesję singularną określonych praw spadkodawcy, przy czym spadkodawca nie ma wpływu na określenie, kto będzie beneficjentem tych przysporzeń. W tym wypadku nie ma bowiem w ogóle oświadczenia spadkodawcy i nie można mówić o jakimkolwiek rozrządzeniu mortis causa. Przykładem mogą być prawa majątkowe ze stosunku pracy, które po śmierci pracownika przypadają wskazanym w ustawie osobom (art. $63^{1} \S 2$ k.p.), na co jednakże spadkodawca nie ma żadnego wpływu. Dochodzi zatem wprawdzie do pozaspadkowej sukcesji singularnej, ale nie do pozatestamentowego rozrządzenia mortis causa.

8 Tekst jedn.: Dz.U. z 2016 r., poz. 291 ze zm.

9 Tekst jedn.: Dz.U. z 2016 r., poz. 1449.

10 Tekst jedn.: Dz.U. z 2016 r., poz. 1776.

11 Tekst jedn.: Dz.U. z 2017 r., poz. 1560.

12 Tekst jedn.: Dz.U. z 2018 r., poz. 613.

13 Dyspozycję pozatestamentową mortis causa przewiduje również art. 831 k.c., który zezwala na wskazanie osoby (osób), którym zostanie wypłacona suma ubezpieczenia w razie śmierci ubezpieczonego. Należy jednak zauważyć, że charakter tej dyspozycji jest inny niż we wska- 
Kwoty wypłacone na podstawie ww. przepisów szczególnych na rzecz wskazanych przez spadkodawcę osób nie należą do spadku, nie są one zatem dziedziczone, nie podlegają działowi w ramach działu spadku, nie sprawuje nad nimi zarządu wykonawca testamentu, nie przechodzą na nabywcę spadku, gdy doszło do jego zbycia. Nie jest możliwe uznanie beneficjenta takiego rozrządzenia pozatestamentowego za niegodnego dziedziczenia, chyba że jest równocześnie spadkobiercą, zapisobiercą lub uprawnionym do zachowku: niegodność dziedziczenia nie pozbawia go jednak praw wynikających z tych dyspozycji. Osoby te nie odpowiadają również za długi spadkowe. Nie oznacza to jednak, że żadne przepisy prawa spadkowego nie znajdują zastosowania do oceny skutków takich czynności. Za najbardziej uzasadnione wydaje się uwzględnienie tych przysporzeń przy ustalaniu zachowku. Przepisy wprowadzające sukcesję singularną mortis causa we wskazanych przypadkach łączy chęć uproszczenia procedury nabycia określonych praw (co do zasady pieniędzy), natomiast z całą pewnością nie mają one na celu stworzenia możliwości pokrzywdzenia osób najbliższych, których ochronie służą przepisy o zachowek. Rozrządzenia takie są - co do treści i skutków - bardzo zbliżone do zapisów windykacyjnych (i darowizn mortis causa), dlatego jako zasadę należy uznać, że wartość ww. praw należy doliczyć do substratu zachowku na takich samych zasadach jak zapisy

zanych wyżej przykładach, bowiem kwoty, których dotyczy dyspozycja, nigdy nie wchodziły do majątku spadkodawcy, nie dochodzi więc tu do sukcesji singularnej. Ta odmienność zmusza do innego traktowania kwot wypłaconych z takiego ubezpieczenia. A. Szpunar, Oznaczenie uposażonego $w$ ubezpieczeniu na życie, w: Ubezpieczenia $w$ gospodarce rynkowej, t. IV, Bydgoszcz 2002, s. 177, wyraźnie opowiedział się za doliczaniem sum wypłaconych na podstawie art. 831 k.c. do spadku przy obliczaniu zachowku. Według Autora wynika to z faktu, że w stosunku waluty mamy do czynienia z przysporzeniem nieodpłatnym. Przeważa jednak pogląd odmienny, w świetle którego sum wypłaconych z ubezpieczenia na życie nie uwzględnia się przy obliczaniu zachowku (A. Dyoniak, Ochrona rodziny w razie śmierci jednego z matżonków, Warszawa-Poznań 1990, s. 148; M. Orlicki, Umowa ubezpieczenia, Warszawa 2002, s. 124; M. Krajewski, Umowa ubezpieczenia. Komentarz, Warszawa 2004, s. 292; B. Kucharski, Ochrona spadkobierców, uprawnionych do zachowku oraz wierzycieli $w$ razie wskazania uposażonego $w$ umowie ubezpieczenia na życie, Prawo Asekuracyjne 2015/1, s. 47 i n.). Za zasadne należy uznać natomiast - przynajmniej w niektórych wypadkach - doliczanie składek wpłacanych na ubezpieczenie na życie. Powinny być one uwzględnione, o ile można je traktować jako darowizny na rzecz uposażonego. Pomniejszają one majątek spadkowy i mają charakter nieodpłatny. Składki w stosunku waluty stanowią bezpłatne przysporzenie na rzecz uposażonego kosztem spadku. (Podobnie B. Kucharski, Ochrona..., s. 47 i n.; odmiennie jednak G. Wolak, Wskazanie uposażonego w umowie ubezpieczenia na życie a ochrona interesów spadkobierców i uprawnionych do zachowku, Prawo Asekuracyjne 2015/2, s. 56-70). 
windykacyjne i darowizny (art. 994 k.c.). Techniczno-prawny sposób przejścia majątku na beneficjentów (sukcesja uniwersalna - singularna), forma oświadczenia (testament - dyspozycje pozatestamentowe) czy normatywna podstawa tych dyspozycji (kodeks cywilny - przepisy szczególne) nie mogą rzutować na - mające znaczenie ogólne - przepisy ograniczające swobodę dysponowania majątkiem mortis causa $\mathrm{z}$ uwagi na potrzebę ochrony osób najbliższych (tj. zachowek).

Trudniej ocenić natomiast możliwość zaliczenia wartości tych rozrządzeń na poczet schedy spadkowej w razie działu spadku. Można przecież argumentować, że dokonując określonej dyspozycji mortis causa na podstawie jednego ze wskazanych przepisów, spadkodawca implicite wyraża swoją wolę co do modyfikacji zasad ustawowych odnoszących się do dziedziczenia kwot objętych tą dyspozycją. Takie rozumowanie należy jednak odrzucić, bo ustawodawca w odniesieniu do darowizn i zapisów windykacyjnych przyjmuje inną optykę: nie zakłada się, że dokonanie darowizny czy ustanowienie zapisu windykacyjnego jest przejawem woli wyłączenia przedmiotu tych czynności z obowiązku doliczenia do spadku na potrzeby działu. Spadkodawca musi w tym zakresie wyrazić swą wolę, co należy rozumieć w ten sposób, że wola ta nie może być wywodzona (wyinterpretowana) z samego faktu dokonania darowizny czy ustanowienia zapisu windykacyjnego, lecz musi wynikać z jakiś innych oświadczeń czy okoliczności. Tak samo należy ocenić inne singularne rozrządzenia pozatestamentowe, tzn. uznać, że jeśli nic innego nie wynika z oświadczenia spadkodawcy lub z okoliczności, to kwoty te należy doliczyć do spadku na takich samych zasadach jak zapisy windykacyjne.

Podsumowując tę część rozważań, należy uznać, że trafnie Sąd Najwyższy przyjął, że kwoty wypłacone na skutek realizacji dyspozycji wkładem bankowym na wypadek śmierci są uwzględniane przy dziale spadku, jak darowizny i zapisy windykacyjne. Nie ma również wątpliwości, że powinny one być uwzględnione także przy ustalaniu zachowku. Z uwagi na fakt, że dyspozycja ta stanowi jedynie przykład jednej z kilku występujących w polskim porządku prawnym podobnych instytucji, zasadę tę trzeba rozciągnąc także na inne przypadki sukcesji singularnej opisane wyżej.

Sąd Najwyższy poszedł w rozumowaniu jednak nawet dalej, bowiem przyjął, że przez darowiznę (w kontekście działu spadku) należy rozumieć wszelkie przysporzenia dokonane przez spadkodawcę pod tytułem darmym. To bardzo szerokie ujęcie stanowi - wbrew temu co czytamy w uzasadnieniu orzeczenia - novum w orzecznictwie. Dotychczas nigdy tak wyraźnie nie wybrzmiała ta dość śmiała teza; przeciwnie - dominowało raczej stanowisko ujmujące pojęcie 
darowizny wąsko ${ }^{14}$. Od dawna należę do zwolenników szerokiego rozumienia darowizny na gruncie przepisów o zachowku (i - ostrożniej - dziale spadku). Uważam, że na gruncie przepisów o zachowku darowizna obejmuje nie tylko umowę z art. 888 k.c., ale również takie nieodpłatne czynności spadkodawcy, które następują z majątku spadkodawcy, powodują zmniejszenie spadku i z punktu widzenia osób uprawnionych mogą prowadzić do takiego samego ich pokrzywdzenia jak dokonanie darowizny (przysporzenia donandi causa kosztem majątku spadkodawcy). Dlatego uważam, że winno uwzględniać się kwoty wypłacone na podstawie pozatestamentowych dyspozycji mortis causa, o których była mowa wyżej, ale także m.in. wartość gospodarstwa rolnego nabytego na podstawie umowy z następcą, o której mowa w art. 84 u.u.s.r..$^{15}$ czy wartość udziału nabytego w wypadku nieodpłatnego zniesienia współwłasności, działu spadku i podziału majątku wspólnego małżonków, a także wartość nieodpłatnie ustanowionego użytkowania czy służebności. Podobnie - choć niekoniecznie identycznie - należałoby to widzieć w kontekście działu spadku. Wydaje się, że formuła, którą posłużył się Sąd Najwyższy, jest jednak zbyt szeroka, bowiem obejmuje wszystkie nieodpłatne przysporzenia, a więc również te, które nie powodują zmniejszenia majątku spadkodawcy, np. użyczenie czy świadczenie usług. Koncepcja, by również tego rodzaju nieodpłatne świadczenia uwzględniać, może prowadzić niekiedy do sprawiedliwego rezultatu, ale nie znajduje chyba wystarczającego umocowania w ustawie. Nie da się postawić na jednej płaszczyźnie prawnej świadczenia usług i przeniesienia prawa. Pójście zbyt daleko w tym kierunku mogłoby niekiedy skutkować swoistym wykreowaniem majątku z niczego: jeśli spadkodawca nie miał nic, ale jednemu z dzieci

14 Tak np. wyrok SA w Białymstoku z dnia 9 stycznia 2013 r., I ACa 714/12; wyrok SA we Wrocławiu z dnia 12 kwietnia 2013 r., I ACa 286/13; wyrok SA w Warszawie z dnia 19 czerwca 2013 r., I ACa 142/13; wyrok SA w Łodzi z dnia 19 lutego 2014 r., I ACA 1010/13; wyrok SA w Warszawie z dnia 11 marca 2014 r., VI ACa 1530/13.

15 Tak np. A. Dyoniak, Ochrona..., s. 133; L. Stecki, Darowizna, Toruń 1998, s. 313; A. Szpunar, Uwagi o obliczaniu wysokości zachowku, Rejent 2002/4, s. 26; M. Niedośpial, Umowa z następca (zagadnienia podstawowe), AUW 1997, s. 91-92, a także SN w uzasadnieniu post z 18.04.2008 r., II CSK 647/07, LEX nr 518174; odmiennie, nietrafnie, na tle dawnego stanu prawnego uchw. SN z 19.02.1991 r., III CZP 4/91, OSNC 1992, nr 9, poz. 163, z glosami M. Niedośpiała, OSP 1993, nr 1, poz. 2, i A. Lichorowicza, OSP 1993, nr 4, poz. 84, i SN w uchwale z 21.06.2012 r., III CZP 29/12, OSNC 2013, nr 1, poz. 7, zgodnie z którą: „Przy ustalaniu zachowku nie uwzględnia się wartości gospodarstwa rolnego przekazanego przez spadkodawcę następcy na podstawie umowy przewidzianej w art. 59 ustawy z dnia 14 grudnia 1982 r. o ubezpieczeniu społecznym rolników indywidualnych i członków ich rodzin (jedn. tekst: Dz.U. z 1989 r., nr 24, poz. 133 ze zm.)”. 
pomagał, świadcząc nieodpłatne usługi, mogłoby się okazać, że drugie z dzieci ma do pierwszego roszczenie o zachowek. Takiego rezultatu chyba ustawodawca nie zamierzył.

Do rozważenia pozostaje jeszcze jeden problem, który wiąże się z elastycznym rozumieniem darowizny, tj. zakres odpowiedzialności za długi spadkowe beneficjenta takiego przysporzenia (np. beneficjenta dyspozycji wkładem bankowym na wypadek śmierci). Za długi spadkowe odpowiadają spadkobiercy i zapisobiercy windykacyjni (art. 1034 i $1034^{1}$ k.c. i $999^{1}$ k.c.), zaś za szczególny dług, jakim jest roszczenie o zachowek - także subsydiarnie obdarowani (art. 1000 k.c.). Nie ma podstawy normatywnej, by uznawać, że beneficjenci przysporzeń z tytułu różnych pozatestamentowych dyspozycji mortis causa odpowiadają za długi spadkowe, choć brak taki należy uważać za wyraźny błąd konstrukcyjny. Jednakże w zakresie zachowku można takiej odpowiedzialności subsydiarnej poszukiwać - skoro określone przysporzenie będzie doliczone jak darowizna do substratu zachowku, to również beneficjent powinien być traktowany jak obdarowany w zakresie odpowiedzialności za zachowek - będzie zatem odpowiadał subsydiarnie i tylko $\mathrm{w}$ granicach istniejącego wzbogacenia (art. 1000 k.c.). 